\title{
Viral and host factors related with histopathologyc activity in patients with chronic hepatitis $B$ and moderate or intermittently elevated alanine aminotransferase levels
}

\author{
E. Molina-Pérez ${ }^{1}$, J. F. Castroagudín ${ }^{1}$, A. Aguilera-Guirao² ${ }^{\text {, E. Otero-Antón }}{ }^{3}$, S. Tomé-Martínez-de- \\ Rituerto $^{3}$, J. Mera-Calviñóo ${ }^{1}$ J. J. Rodríguez-Calviño ${ }^{2}$ and J. E. Domínguez-Muñoz ${ }^{1}$
}

Services of ${ }^{1}$ Digestive Diseases, ${ }^{2}$ Microbiology and ${ }^{3}$ Internal Medicine. Hospital Clínico Universitario de Santiago de Compostela. A Coruña, Spain

\begin{abstract}
Objective: viral and host factors are related with progression of pathological lesion in chronic hepatitis $\mathrm{B}$. We analyzed these factors in patients with moderate or intermittently elevated ALT levels, and its threshold that determinate significant histological activity.

Patients and methods: retrospective analyses of viral and host parameters in 89 consecutive chronic hepatitis B patients biopsied because of moderate or intermittently elevated ALT levels $[1-2 \times$ ULN $(U L N=39 \mathrm{IU} / \mathrm{mL})]$ and/or DNA-HBV $>2 \times 10^{3}$ $\mathrm{IU} / \mathrm{mL}$ in AntiHBe+ patients. It was analyzed age, gender, ALT levels, $\mathrm{HBeAg}$, viral load and genotype. It was considered advanced histological lesion a Knodell Score $(\mathrm{KS})>7$ and histological lesion indicating treatment, lobular inflammation $\geq 2$ or fibrosis $\geq 2$ according to Scheuer Classification.

Results: KS $>7$ and histological lesion indicating treatment was found in 47.8 and $60.7 \%$ respectively. It was observed relationship between age, male gender, ALT levels and viral load with histological damage $(p<0.05)$. Frequency of advanced lesion indicating treatment was upper in patients with ALT levels > ULN (69.1 vs. 47.1\%, $p=0.04)$. There were not significant upper frequencies of advanced lesion when a cut-off of 40 years or DNA$\mathrm{HBV}>2 \times 10^{3} \mathrm{IU} / \mathrm{mL}$ viral load or serological status HBeAg was considerate. Histological activity was lesser in genotype D patients than those infected with others genotypes $(p<0.05)$.

Conclusion: upper frequency of advanced histological lesion in chronic hepatitis B patients with moderate or intermittently elevated ALT levels make recommended liver biopsy, independent of viral load and serological status $\mathrm{HBeAg}$. Other factors like age, gender or genotype can help to indicate biopsy in individual cases.
\end{abstract}

Key words: Chronic hepatitis B. HBV infection. Liver biopsy. Histological lesion. Alanine aminotransferase. DNA-HBV. Genotype.

\begin{abstract}
RESUMEN
Objetivo: analizar factores virales y del huésped relacionados con actividad histológica en un subgrupo de pacientes con hepatitis crónica $\mathrm{B}$ y elevación intermitente o moderada de alanina aminotransferasa (ALT), y el umbral que determine daño histológico indicativo de tratamiento.
\end{abstract}

Pacientes y métodos: análisis retrospectivo de parámetros virales y del huésped en 89 pacientes con hepatitis crónica B biopsiados consecutivamente por elevación intermitente o moderada de ALT [1-2 x USN (USN = $39 \mathrm{UI} / \mathrm{mL})]$. Fueron analizados edad, sexo, ALT, HBeAg, carga viral y genotipo. Se consideró como lesion histologica avanzada un Índice de Knodell $(\mathrm{IK})>7$, e indicativa de tratamiento la inflamación lobulillar $\geq 2$ o fibrosis $\geq 2$ según la clasificación de Scheuer.

Resultados: existió un IK $>7$ y lesión indicativa de tratamiento en 47,8 y $60,7 \%$, respectivamente. La edad, sexo varón, ALT y carga viral se relacionaron con lesión avanzada $(p<0,05)$. La frecuencia de lesión indicativa de tratamiento fue mayor en pacientes con ALT > USN (69,1 vs. 47,1\%, p = 0,04). La frecuencia de lesión avanzada no fue significativamente mayor cuando se consideraron como puntos de corte la edad de 40 años o DNA$\mathrm{VHB}>2 \times 10^{3} \mathrm{UI} / \mathrm{mL}$ o positividad de $\mathrm{HBeAg}$. Se observó menor actividad histológica en pacientes con genotipo $\mathrm{D}$ respecto a aquellos infectados con otros genotipos ( $p<0,05)$.

Conclusión: una mayor frecuencia de lesión avanzada en pacientes con hepatitis crónica B y elevación intermitente o moderada de ALT hacen recomendable la biopsia hepática independientemente de la carga viral y positividad de $\mathrm{HBeAg}$. Factores como la edad, sexo o genotipo pueden ayudar de forma individual a dicha indicación.

Palabras clave: Hepatitis crónica B. Infección por VHB. Biopsia hepática. Lesión histológica. Alanina aminotransferasa. ADNVHB. Genotipo.

Molina-Pérez E, Castroagudín JF, Aguilera-Guirao A, Otero-Antón E, Tomé-Martínez-de-Rituerto S, Mera-Calviño J, Rodríguez-Calviño JJ, Domínguez-Muñoz JE. Viral and host factors related with histopathologyc activity in patients with chronic hepatitis $B$ and moderate or intermittently elevated alanine aminotransferase levels. Rev Esp Enferm Dig 2010; 102: $519-525$.

Received: 02-02-10

Accepted: 11-03-10.

Correspondence: Esther Molina Pérez. Servicio de Aparato Digestivo. Hospital Clínico Universitario de Santiago. C/ Choupana, s/n. 15706 Santiago de Compostela.e-mail: esther.molina.perez@sergas.es 


\section{INTRODUCTION}

Chronic hepatitis B currently affects around 350-400 million people worldwide, overall being the first cause of cirrhosis or hepatocellular carcinoma. It is estimated that is responsible for upper one million deaths/year $(1,2)$.

Its natural history is complex, establishing four phases in its evolution: immune tolerance, immune clearance, inactive carrier state and chronic hepatitis antiHBe positive, defined by aminotranferase levels, viral load, serological status $\mathrm{HBeAg}$ and histopathological lesion (3). Progression to advanced fibrosis in chronic hepatitis B is a variable dynamic process, with rapid, slow or sporadic progression depending on the cases. Incidence of cirrhosis is twofold in patients with antiHBe positive and, in $\mathrm{Eu}-$ rope, once established, accumulated risk of hepatocellular carcinoma or death is 10 and $15 \%$, respectively $(2,4)$.

Chance of change the natural history of the illness by means of antiviral therapies do necessary a careful knowledge of factors related with histological activity, as a possible threshold of these indicating the optimal moment to start antiviral treatment (5). A known relationship between ALT levels and progression of histological damage has done that be recommended antiviral therapy in patients with ALT levels upper twofold the upper limit of the normality (ULN) and liver biopsy when they are situated among 1-2 x ULN (5-8). Nevertheless it has communicated the existence of pathological lesion indicating antiviral treatment in 13 to $37 \%$ of patients with a normal aminotransferase levels $(9,10)$. It has neither been defined which is the adequate ULN of ALT that permit to identify a greater number of patients with significant histological lesion. It has recommended an adjusted in ULN of ALT levels according to sex and body mass index, due to influence of these parameters in those levels $(11,12)$. High levels of DNA load have associated with development of cirrhosis (13) and hepatocellular carcinoma (14). Nevertheless, low or undetectable levels of DNA do not eliminate the risk of clinical events (15), being observed a liver damage indicating treatment even in a $62 \%$ of patients with DNA-VHB $<2 \times 10^{3} \mathrm{IU} / \mathrm{mL}(13,16)$. It has neither been defined the exact role of different genotypes in the progression of the histopathological lesion $(17,18)$.

Our objective is to analyze the relationship between host and viral factors and severity of histopathological lesion in patients with chronic hepatitis $\mathrm{B}$. We evaluated the threshold of these factors related to the histological activity that can modify therapy decision in these patients.

\section{PATIENTS AND METHODS}

\section{Patients}

Retrospective analysis of viral and host parameters related to advanced histological lesion in 89 of 165 Caucasian patients with chronic hepatitis B submitted to liver biopsy between January 2000 and December 2007 in our centre. ALT levels and viral load was determinate every three months during a year, indicating liver biopsy in those patients with intermittent or persistent ALT elevation upper ULN and/or DNA-HBV $>2 \times 10^{3} \mathrm{UI} / \mathrm{mL}$ in patients AntiHBe positive. It was considered intermittent ALT elevation when any subsequent determination showed ALT < ULN. They were excluded those patients with chronic hepatitis $\mathrm{B}$ whose we done not indicate liver biopsy by presenting persistently normal ALT levels with DNA-HBV > $2 \times 10^{4} \mathrm{IU} / \mathrm{mL}$ in patient $\mathrm{HBeAg}$ positive (immune tolerance phase), or $<2 \times 10^{3} \mathrm{IU} / \mathrm{mL}$ in patients antiHBe positive (inactive carrier state). They were excluded too those patients with evidence of liver illness because of other etiology, pregnant, consumption of more than $50 \mathrm{~g}$ of ethanol/day in men and $30 \mathrm{~g}$ of ethanol/day in women or receiving antiviral therapy before the liver biopsy.

\section{Host factors}

They were included to analyses age, gender, ALT levels and platelet account at the moment of the liver biopsy. It was considered to analyses, according to the published guidelines (5-8), a cut-off of 40 years. Biochemical and hematological parameters were obtained using the habitual automatic analyzers. The ULN of ALT was $39 \mathrm{IU} / \mathrm{mL}$ for men and women, being categorized ALT levels in order to analyses in below to ULN, between 1-1.5 x ULN and upper $1.5 \mathrm{x}$ ULN. They were not considered to analyze a cut-off below ULN, because most of these patients showed ALT > ULN in any moment before liver biopsy indicating them.

\section{Viral factors}

Serum HBV markers (HBsAg, $\mathrm{HBeAg}$, antiHBcore, antiHBcore-IgM, antiHBe and antiHBs) were determined for each patient by the system AxSYM ${ }^{\circledR}$ (Abbott Diagnostics, USA) by means of an immunoassay in micro particles that utilizes fluorescent detection. DNAHBV was quantified by molecular hybridization followed of amplification of the signal (bDNA), whose limits of detection is situated in $2 \times 10^{3} \mathrm{cp} / \mathrm{mL}$ (VERSANT $^{\circledast}$ HBV bDNA 3,0 Assay, Siemens Heathcare USA). Viral load was change in IU/mL using converting factor $1 \mathrm{IU} / \mathrm{mL}=5.26$ copies $/ \mathrm{mL}$. To analyze, the viral load was categorized in three groups: $<2 \times 10^{3} \mathrm{IU} / \mathrm{mL}$, between $2 \times 10^{3}-2 \times 10^{4} \mathrm{IU} / \mathrm{mL}$ and $>2 \times 10^{4} \mathrm{IU} / \mathrm{mL}$. Finally, genotype characterization of HBV was carried out by means of reversed hybridization with a trial of lineal probe (LiPA) designed to identify the different genotypes A-H of the HBV (INNO-LiPA ${ }^{\circledR}$ HBV Genotyping, Innogenetics Belgium). For all procedures it was observed precise instructions of the manufacturer. 


\section{Liver biopsy}

Sample biopsy was analyzed by the same pathologist, blinded for host and viral parameters. It was classified the histological lesion according to the Knodell Score (KS) (19) with a scale of $0-18$ points, and degrees of inflammatory grade $(\mathrm{G})$ in a scale of $0-14$ and stage of fibrosis (F) of 0-4. It was considered to analyze, in an arbitrary form, advanced histological lesion as upper scoring of 7 points in KS, an inflammation grade upper 4 points or a fibrosis stage upper 2 points. It was considered, according to published clinical guidelines (5-8), histological lesion indicating treatment as lobular inflammation $(\mathrm{L}) \geq 2$ or fibrosis $(\mathrm{F}) \geq 2$ according to the Scheuer Classification (20).

\section{Statistical analysis}

Results have been expressed as median or mean \pm standard deviation as were appropriate. Data were analyzed using the Statistical Program for Social Sciences version 15.0 (SPSS Inc., Chicago, IL). Analysis was carried out by means of Chi-Square and Fisher exact test for categorical variables. Student $t$ test was used for comparison of parametric quantitative data, while nonparametric data were analyzed by Mann-Whitney test. Relations between two quantitative variables were performed by Spearman's correlation analysis. A multivariable logistic regression was carried to evaluate predictive factors of advanced histological lesion. Two tailed $\mathrm{P}$ value lesser than 0.05 was considered statistically significant.

\section{RESULTS}

\section{Population characteristics}

Data of 66 men and 23 women with mean age of $40.8 \pm$ 14.4 years and ALT level $73.8 \pm 67.3 \mathrm{IU} / \mathrm{mL}$ were analyzed. Before biopsy, $38.2 \%$ presented ALT levels below ULN and $44.8 \%$ DNA-HBV below $2 \times 10^{3} \mathrm{IU} / \mathrm{mL}$, being $62.9 \%$ of patients antiHBe positive. Thirty-nine patients (47.8\%) presented a KS $>7$ points, with histological activity indicating treatment in $54(60.7 \%)$. Biochemical, viral and histological characteristics of studied population is summarized in table I.

\section{Age and gender}

It was observed correlation between age and severity of histological lesion measured as total scoring in KS $(\mathrm{r}=$ $0.26 ; \mathrm{p}=0.03)$, lobular inflammation $(\mathrm{r}=0.21 ; \mathrm{p}=0.04)$ and fibrosis $(\mathrm{r}=0.26 ; \mathrm{p}=0.01) .47$ patients $(52.8 \%)$ were older than 40 years at the moment of liver biopsy. According to this cut-off of age there were not observed significant differences in severity or frequency of advanced histological activity.
Table I. Characteristics of studied population

\begin{tabular}{|c|c|}
\hline Age (years) & $40.8 \pm 14.4$ \\
\hline Gender male/female ( $n$ ) & $66 / 23$ \\
\hline ALT mean (IU/mL) & $73.8 \pm 67.3$ \\
\hline ALT median, IU/mL (range) & $48(13-342)$ \\
\hline \multicolumn{2}{|l|}{ ALT, n (\%) } \\
\hline$<$ ULN & $34(38.2)$ \\
\hline $1-1.5 \times$ ULN & $23(25.8)$ \\
\hline$>1.5 \times$ ULN & $33(37.1)$ \\
\hline Platelets, mean $\left(10^{9} /\right)$ & $186 \times 10^{3} \pm 59 \times 10^{3}$ \\
\hline \multicolumn{2}{|l|}{ Serological status HBe, n (\%) } \\
\hline HBeAg & $33(37.1)$ \\
\hline AntiHbe & $56(62.9)$ \\
\hline DNA-HBV median, IU/mL (range) & $2.9 \times 10^{3}\left(0-2 \times 10^{8}\right)$ \\
\hline \multicolumn{2}{|l|}{ DNA-HBV, UI/mL, n (\%) } \\
\hline$<2 \times 10^{3}$ & $39(44.8)$ \\
\hline $2 \times 10^{3}-2 \times 10^{4}$ & $15(17.2)$ \\
\hline$>2 \times 10^{4}$ & $33(37.9)$ \\
\hline \multicolumn{2}{|l|}{ Genotipe, n (\%) } \\
\hline A & $9(18)$ \\
\hline D & $39(78)$ \\
\hline $\mathrm{F}$ & $1(2)$ \\
\hline $\mathrm{H}$ & $1(2)$ \\
\hline Total Knodell Score, median (range) & $6(0-18)$ \\
\hline Knodell grade, median (range) & $5(0-14)$ \\
\hline Knodell stage, median (range) & $1(0-4)$ \\
\hline Knodell score $>7, n(\%)$ & $39(47,8)$ \\
\hline Knodell grade > 4, n (\%) & $65(73)$ \\
\hline Knodell stage $>2, n(\%)$ & $26(29.2)$ \\
\hline Scheuer lobular immflamation $\geq 1, n(\%)$ & $49(55.1)$ \\
\hline Scheuer fibrosis $\geq 1, n(\%)$ & $33(37.1)$ \\
\hline Indication of therapy, n (\%) & $54(60.7)$ \\
\hline
\end{tabular}

Histological lesion measured like scoring KS, grade of inflammation and stage of fibrosis was upper in males ( $p$ $<0.05)$. Frequency of patients with KS > 7 (50 vs. 26.1\%; OR: 2.83; IC 95\%: 1.01-7.84; $\mathrm{p}=0.05), \mathrm{G}>4$ (78.8 vs. 56.5\%; OR: 2.85; IC 95\%: $1.05-7.87 ; \mathrm{p}=0.05)$ and $\mathrm{F}>2$ (53 vs. 17.4\%; OR: 5.36; IC 95\%: 1.7-16.6; $\mathrm{p}=0.03$ ) was also upper in males.

\section{ALT levels}

There were significant correlation between ALT levels and inflammation grade $(\mathrm{r}=0.37, \mathrm{p}=0.0001)$ and total scoring KS ( $r=0.47, p=0.0001)$.

Before biopsy, 34 patients (38.2\%) presented ALT < ULN. $47.1 \%$ of them presented a histopathological activity indicating treatment, with $\mathrm{L} \geq 2$ in $41.2 \%$ and $\mathrm{F} \geq 2$ in $29.4 \%$.

Patients with ALT levels $>$ ULN $(n=55)$ presented a histological lesion measured like total scoring KS ( $\mathrm{p}=$ $0.02)$, as grade of inflammation $(\mathrm{p}=0.05)$ upper than patients with normal ALT levels. Frequency of patients with L $\geq 2$ in Scheuer's Classification (63.6 vs. 41.2\%; OR, 2.5; IC 95\%: $1.04-5.99, \mathrm{p}=0.04)$ and those with a KS $>7(52.7 v s$. 29.4\%; OR, 2.67; IC 95\%: 1.07-6.6, p = 0.04) were upper than patients with normal ALT levels, too. It was expressed in a significant increase on indication of antiviral therapy in 
this group of patients $(69.1 \mathrm{vs.} 47.1 \%$; OR, 2.5; IC 95\%: 1.04-6.03, $p=0.04)$. Characteristics of patients with ALT levels over or below ULN are summarized in table II.

Table II. Characteristics of patients according to ALT upper or lower ULN

\begin{tabular}{|c|c|c|c|}
\hline Characteristics & $\begin{array}{c}A L T<U L N \\
(n=34)\end{array}$ & $\begin{array}{c}A L T>U L N \\
(n=55)\end{array}$ & $p$ \\
\hline Age & $41.4 \pm 14.5$ & $40.5 \pm 14.5$ & 0.8 \\
\hline Age $>40, n(\%)$ & $19(55.9)$ & $28(50.9)$ & 0.4 \\
\hline Gender, male, $n(\%)$ & $22(64.7)$ & $44(80)$ & 0.1 \\
\hline ALT mean $(I U / m L) *$ & $28.5 \pm 7.9$ & $101.8 \pm 72.4$ & 0.0001 \\
\hline \multicolumn{4}{|c|}{ Serological status HBe, $\mathrm{n}(\%)$} \\
\hline HBeAg & $10(29.4)$ & $23(43.4)$ & 0.3 \\
\hline AntiHbe & $25(73.5)$ & $31(58.5)$ & 0.1 \\
\hline \multicolumn{4}{|l|}{ DNA-HBV median } \\
\hline IU/mL (range)* & $1,9 \times 10^{3}\left(0-4,9 \times 10^{6}\right)$ & $17 \times 10^{3}\left(0-2 \times 10^{8}\right)$ & 0.04 \\
\hline \multicolumn{4}{|l|}{ DNA-HBV, $\mathrm{n}(\%)$} \\
\hline$<2 \times 10^{3} \mathrm{IU} / \mathrm{mL}$ & $17(50)$ & $22(41.5)$ & 0.4 \\
\hline $2 \times 10^{3}-2.10^{4} \mathrm{IU} / \mathrm{mL}$ & $8(23.5)$ & $7(13.2)$ & 0.2 \\
\hline$>2 \times 10^{4} \mathrm{IU} / \mathrm{mL}$ & $9(26.5)$ & $24(45.3)$ & 0.1 \\
\hline \multicolumn{4}{|l|}{ Genotype, n (\%) } \\
\hline A & $2(13.3)$ & $7(20)$ & 0.7 \\
\hline D & $13(86.7)$ & $26(74.3)$ & 0.5 \\
\hline \multicolumn{4}{|l|}{ Total Knodell Score, } \\
\hline median (range)* & $5(0-18)$ & $7(2-18)$ & 0.016 \\
\hline Grade Knodell, median (range)' & $4(0-14)$ & $5(1-14)$ & 0.05 \\
\hline Stage Knodell, median (range) & $1(0-4)$ & $1(0-4)$ & 0.2 \\
\hline Knodell Score > 7, n (\%)* & $10(29.4)$ & $29(52.7)$ & 0.04 \\
\hline Grade Knodell > 4, n (\%) & $22(64.7)$ & $43(78.2)$ & 0.2 \\
\hline Stage Knodell > 2, n (\%) & $8(23.5)$ & $18(32.7)$ & 0.5 \\
\hline \multicolumn{4}{|l|}{ Lobular Inflammation } \\
\hline Scheuer $\geq 1, n(\%)^{*}$ & $14(41.2)$ & $35(63.6)$ & 0.04 \\
\hline Fibrosis Scheuer $\geq 1, \mathrm{n}(\%)$ & $10(29.4)$ & $23(41.8)$ & 0.3 \\
\hline Indication of therapy, $n(\%)^{*}$ & $16(47.1)$ & $38(69.1)$ & 0.04 \\
\hline
\end{tabular}

When data were analyzed according to classification ALT levels in < ULN, 1-1.5 x ULN or > $1.5 \times$ ULN, it was not observed significant differences in severity or frequency of histopathological lesion between the two first groups. Frequency of patients with KS > 7 (72.7 vs. $17.4 \%$, OR 12.49; IC 95\%: 3.42-45.29, $\mathrm{p}=$ $0.00001), \mathrm{G}>4(87.9$ vs. $60.9 \%$; OR, 5.2; IC $95 \%$ $1.39-21.89, \mathrm{p}=0.01)$ and $\mathrm{F}>2(45.5$ vs. 8.7\%; OR, 7.61; IC 95\%: $1.73-33.7 \%, \mathrm{p}=0.003$ ) were upper in those patients with ALT levels $>1.5 \mathrm{x}$ ULN than those with ALT levels between 1-1.5 x ULN. Severity of histological lesion measured as $\mathrm{F} \geq 2(54.5$ vs. $17.4 \%$; OR, 5.52; IC 95\%: $1.6-19, \mathrm{p}=0.05)$ and $\mathrm{L} \geq 2(75.8 v \mathrm{~s}$. 43.5\%; OR, 4.37; IC 95\%: 1.4-13.7, $\mathrm{p}=0.01$ ) according to Scheuer's Classification was upper in patients with ALT levels $>1.5 \times$ ULN, too, expressing in an upper percentage of patients with histological damage indicating treatment $(78.8 v$ s. $52.2 \%$; OR, 3.75; IC 95\%: $1.15-12.12, \mathrm{p}=0.03)$.

\section{Viral load}

It was observed correlation between DNA load and grade of inflammation $(r=0.23 ; p=0.03)$, like as with histopathological lesion indicating treatment $(\mathrm{r}=0.23 ; \mathrm{p}=$ $0.03)$. From 40 patients with DNA-HBV $<2 \times 10^{3} \mathrm{IU} / \mathrm{mL}$, $19(48.7 \%)$ presented a KS $>7$ and $28(71.8 \%)$ histological lesion indicating treatment. There were not observed significant differences in histological damage respect to those with DNA-HBV $>2 \times 10^{3} \mathrm{IU} / \mathrm{mL}$. Neither was found significant differences in severity or frequency of histopathological activity when DNA-HBV $>2 \times 10^{4} \mathrm{IU} / \mathrm{mL}$ was chosen like cut-off in order to analysis.

After categorization viral load in three groups: $<2 \mathrm{x}$ $10^{3} \mathrm{IU} / \mathrm{mL}, 2 \times 10^{3}-2 \times 10^{4} \mathrm{IU} / \mathrm{mL}$ and $>2 \times 10^{4} \mathrm{IU} / \mathrm{mL}$, the only significant difference observed among all parameters evaluated was a upper percentage of histological lesion indicating treatment in patients with DNA-HBV < $2 \times 10^{3} \mathrm{IU} / \mathrm{mL}$ respect to those with DNA-HBV between $2 \times 10^{3}-2 \times 10^{4} \mathrm{IU} / \mathrm{mL}$ (71.8 vs. 40\%; OR 3.81; IC 95\%: $1.09-13.27, \mathrm{p}=0.05)$.

\section{Serological status HBeAg/antiHBe}

There were not observed significant differences in the severity or frequency of histological lesion among patients with $\mathrm{HBeAg}$ respects those with antiHBe positive. Neither difference in analyzed parameters was observed when it was considered a cut-off of DNA-HBV of $2 \times 10^{4}$ $\mathrm{IU} / \mathrm{mL}$ in patients with $\mathrm{HBeAg}$ positive, or a cut-off of 2 $\mathrm{x} 10^{3} \mathrm{IU} / \mathrm{mL}$ in those antiHBe positive.

\section{Genotype}

From 50 patients genotyped, $39(78 \%)$ presented genotype D and 9 (18\%) genotype A. In patients with genotype $\mathrm{D}$ it was found lesser histological lesion measured as total KS score $(p=0.03)$ and grade of inflammation $(p=0.01)$ without differences in the fibrosis stage $(p=0.03)$. It was not express in an upper percentage of patients with histological activity indicating treatment between those with genotypes different from $\mathrm{D}(61.5$ vs. $72.7 \%, \mathrm{p}=\mathrm{ns})$.

\section{Platelets account}

It was found correlation between platelets account and histological lesion measured as total KS ( $\mathrm{r}=0.46$; $\mathrm{p}=$ $0.001)$, grade of inflammation $(r=0.6 ; p=0.0001)$ and fibrosis stage $(r=0.49 ; p=0.0001)$.

\section{Histopathological lesion}

Mean age was upper in patients with a KS $>7(50 \pm$ $36 v s .45 .7 \pm 15.5, \mathrm{p}=0.006)$ and $\mathrm{F} \geq 2(46.3 \pm 14.8 v s$. 
$38.5 \pm 13.7, \mathrm{p}=0.01)$. There were observed upper mean ALT levels in patients with advanced histological lesion measured as $\mathrm{KS}>7(101 \pm 75.9 v s .52 .6 \pm 50.7, \mathrm{p}=$ $0.0001)$, so as lower mean platelets account $\left(146 \times 10^{3} \pm\right.$ $52 \times 10^{3}$ vs. $\left.217 \times 10^{3} \pm 44 \times 10^{3}, \mathrm{p}=0.0001\right)$.

Aside from lower frequency and severity of histological activity in patients with genotype $\mathrm{D}$, neither viral factor was associated to that. In multivariate analysis, low account of platelets (OR, 0.52; IC 95\%: 0.0005-0.0002, p $<0.001$ ), infection with genotype different from D (OR, 3.7; IC 95\%: 1.2-6.12, $\mathrm{p}<0.001)$ and DNA-HBV $<2 \mathrm{x}$ $10^{3} \mathrm{IU} / \mathrm{mL}$ (OR, 3.16; IC 95\%: 1.01-5.35, p < 0.001) were independent factors in severity of histological activity measured like grade of inflammation and total KS. Inflammation grade was an independent factor in severity of the fibrosis (OR, 1.68; IC 95\%: 1.25-2.26, p < 0.001 ). If known parameters before biopsy was analyzed, a low account of platelets $(\mathrm{p}<0.01)$ and DNA $<2 \times 10^{3}(\mathrm{p}<$ 0.05 ) were independent factors related with severity of fibrosis. According to binary logistic regression a low account of platelets $(\mathrm{p}<0.01)$ and ALT levels $>60 \mathrm{IU} / \mathrm{mL}$ $(\mathrm{p}<0.01)$ were independent variables related with advanced histological lesion measured as $\mathrm{KS}>7$.

In 54 patients (60.7\%) histological lesion was indication of antiviral therapy. These patients respect to those that did not require treatment presented significant difference in mean age $(43.1 \pm 15$ vs. $37.3 \pm 12.9, \mathrm{p}=0.05)$, ALT levels $(90.4 \pm$ $78.2 v s .48 .1 \pm 32.8, \mathrm{p}=0.001)$, platelets account $\left(168 \times 10^{3} \pm\right.$ $59 \times 10^{3}$ vs. $\left.214 \times 10^{3} \pm 47 \times 03, p=0.0001\right)$, viral load $(2.5 \times$ $10^{6} \pm 576 \times 10^{3}$ vs. $\left.17 \times 10^{6} \pm 4.8 \times 10^{6}, \mathrm{p}=0.03\right)$ and frequency of patients with ALT $>1.5 \times$ ULN $(p<0.05)$. By means logistic regression, platelets account $(\mathrm{p}<0.01)$ and DNA-HBV $<2 \times 10^{3} \mathrm{IU} / \mathrm{mL}(\mathrm{p}=0.01)$ are independent factors from histological lesion indicating treatment. Characteristics of both groups are summarized in table III.

Table III. Characteristics of patients according to histological lesion indicating treatment

\begin{tabular}{lccc}
\hline Characteristics & $\begin{array}{c}\text { Treatment } \\
(n=54)\end{array}$ & $\begin{array}{c}\text { No treatment } \\
(n=35)\end{array}$ & $p$ \\
\hline Age $^{*}$ & $43.1 \pm 15$ & $37.3 \pm 12.9$ & 0.05 \\
Age $>40, n(\%)$ & $30(55.6)$ & $17(48.6)$ & 0.66 \\
Gender, male, $n(\%)$ & $42(77.8)$ & $24(68.6)$ & 0.45 \\
ALT mean $(I U / m L)^{*}$ & $9.4 \pm 78.2$ & $48.1 \pm 32.8$ & 0.001 \\
Platelets, mean $\left(10^{9} / L\right)^{*}$ & $168 \times 10^{3} \pm 59 \times 10^{3}$ & $214 \times 10^{3} \pm 47 \times 10^{3}$ & 0.0001 \\
ALT, $n(\%)$ & & & \\
$<$ ULN* & $16(29.2)$ & $18(51.4)$ & 0.04 \\
$1-1.5 \times$ USN & $12(22.2)$ & $11(31.4)$ & 0.45 \\
$>1.5 \times$ USN* & $26(48.1)$ & $7(20)$ & 0.007 \\
DNA-HBV mean UII/mL* & $2.5 \times 10^{6} \pm 5.7 \times 10^{5}$ & $17 \times 10^{6} \pm 4.8 \times 10^{6}$ & 0.03 \\
DNA-HBV, $n(\%)$ & & & \\
$<2 \times 10^{3} \mathrm{UI} / \mathrm{mL}$ & $28(52.8)$ & $11(32.4)$ & 0.08 \\
$2 \times 10^{3}-2 \times 10^{4} \mathrm{UI} / \mathrm{mL}$ & $6(11.3)$ & $9(26.5)$ & 0.08 \\
$>2 \times 10^{4} \mathrm{UI} / \mathrm{mL}$ & $19(35.8)$ & $14(41.2)$ & 0.66 \\
Genotype, $\mathrm{n}(\%)$ & & & \\
$\mathrm{A}$ & $6(18.8)$ & $3(16.7)$ & 0.9 \\
$\mathrm{D}$ & $24(75)$ & $15(83.3)$ & 0.72 \\
\hline${ }^{*} \mathrm{p}<0.05$. & & &
\end{tabular}

\section{DISCUSSION}

Multiple host and viral factors have been related with progression of HBV chronic infection. Due the possibility of change its natural history by mean treatment, our objective in this retrospective study, was to evaluate the influence of such factors on presence of advanced histological lesion in a cohort of patients submitted for liver biopsy because of suspecting that progression.

To exclude those patients with permanently normal levels of ALT could explain the high number of them with histological lesion indicating treatment $(60.7 \%)$ and significant advanced lesion (47.8\%) in our series. Probably this high frequency of advanced histological lesion reduces the differences among analyzed factors.

It has been related age with severity of histological lesion. A cut-off of 40 years old has been proposed as predictive of advanced histological damage $(13,14,21,22)$. Also in our series, age was correlated with severity of the histological lesion. Nevertheless, such cut-off did not show significant differences in severity or frequency of histological damage. It may be due to the different age of acquisition of infection in our area that involves a smaller time of evolution. Thus, although the age should be a factor to consider, especially if the moment of the infection is known, should have more studies to consider a determined cut-off of age in ours medium.

It has been shown an incidence two to six fold higher of cirrhosis, hepatocellular carcinoma and death by chronic hepatitis B in males, being unknown the cause of that $(13,21)$. In our series similar findings are present, with significant differences in prevalence of infection, severity and frequency of histological lesion regard to women.

ALT levels are one of the most important predictive factors of advanced histological lesion included in clinical guidelines to management of HBV infection. In these, it has been indicated antiviral therapy in patients with ALT levels $>2 \times$ ULN and liver biopsy to evaluate severity of histopathological lesion in those with ALT levels between 1-2 x ULN $(5,6)$. In our series, patients with ALT upper $60 \mathrm{IU} / \mathrm{mL}$ presented advanced histological lesion in $72.7 \%$ of cases, that indicated treatment in $78.8 \%$. It is significantly upper than frequency of lesion found in patients with ALT $<$ ULN or $<1.5 \times$ ULN (17.4 and $52.2 \%$ respectively, $\mathrm{p}<0.01$ ), shown as an independent variable to the presence of advanced histological lesion $(\mathrm{p}<0.01)$. This would support, so the doubtful benefit of liver biopsy in patients with ALT $>1.5 \mathrm{x}$ ULN, as the need to redefine the ULN in ours medium, as already has been suggested in other series $(9,11,12)$.

There are scarce references about of severity of histopathological lesion in patients with persistently normal ALT $(5,6)$. Lai et al. (9) have reported advanced histological lesion in $37 \%$ of patients with persistently normal ALT, increasing to $65 \%$ in the series of Kumar et al. (10) when it is analyzed patients with intermittent eleva- 
tion of ALT. Moreover, Park et al. (23) have communicated an increased progression of illness in those patients that do not normalize ALT after intermittent elevations of them. In our series has been observed histological lesion indicating treatment in $47.1 \%$ of patients with normal ALT levels and in 52.2\% of those with levels among 1$1.5 \times$ ULN. That supports the indication of liver biopsy in patients with intermittent elevation of ALT, even after the subsequent normalization of them.

REVEAL-HBV (11) study, carried out in an extensive population of patients with chronic hepatitis B in Taiwan, has shown correlation between viral load and progression of the illness. Even though the evolution is worse with DNA load upper $2 \times 10^{3} \mathrm{IU} / \mathrm{mL}$, lower levels do not eliminate this risk $(13,14,24)$. It is unknown if this cut-off of viral load is applicable in areas where the infection is acquired later and $\mathrm{HBeAg}$ clearance and seroconversion occurs in a premature form. Recently, Papatheodoris et al. (16) have reported an incidence of histological lesion indicating treatment in $62 \%$ of patients with DNA-HBV $<2 \times 10^{3} \mathrm{IU} / \mathrm{mL}$ and persistent or intermittently elevated ALT levels, opposed to $16.6 \%$ in those patients with DNA load $>2 \times 10^{3} \mathrm{IU} / \mathrm{mL}$ and persistently normal ALT levels. It signifies that a single cut-off in viral load is not sufficient to diagnosis of inactive carrier state, like to predict progression in histological damage. It is too necessary a narrow monitoring of ALT levels to take decisions about diagnosis and/or treatment. Similarly, in our series that assessed patients with intermittently or moderate ALT levels elevation, has been observed histopathological lesion indicating therapy in $71.8 \%$ of patients with DNA-HBV $<2 \times 10^{3} \mathrm{IU} / \mathrm{mL}$ and advanced liver lesion in $48.7 \%$, without significant differences respect to those with DNA-HBV $>2 \times 10^{3} \mathrm{IU} / \mathrm{mL}(52.1$ and $39.6 \%$ respectively). In multivariate analysis a viral load $<2 \times 10^{3}$ $\mathrm{UI} / \mathrm{mL}$ was an independent factor in severity of liver damage measured as total $\mathrm{KS}$, grade of inflammation and stage of fibrosis, as well as in antiviral therapy indication $(\mathrm{p}<0.01)$. Perhaps the elevate frequency of histolopathological lesion could be due to a diagnose bias derived of indication of liver biopsy in patients with intermittent or persistently moderate ALT levels elevations, in a population with median DNA-HBV of $2.9 \times 10^{3}\left(0-2 \times 10^{8}\right)$ $\mathrm{IU} / \mathrm{mL}$.

Unlike other series $(13,25)$, we have not found significant difference in histological lesion according to serological $\mathrm{HBeAg}$ status, even after to analyzed it in function of viral load. It was probably due to a diagnose bias commented.

There were growing, although disagreement, evidences of role of different genotypes in the progression of illness (26). Genotype D that has associated to increased prevalence of antiHBe positive, is the most frequent one in our area. Even though Sánchez-Tapias et al. (17) have reported greater histological damage in patients infected with this genotype regard to genotype A, it was unconfirmed in other series (27). In ours series lesser severity of liver lesion was observed in patients infected with genotype $\mathrm{D}$, due to decreased grade of inflammation. It was not reach meaning in therapy indication due to high percentage of advanced histological lesion in both groups. Infection with a different genotype than D was related with a greater severity of histological activity measured as total KS and grade of inflammation, without relation with stage of fibrosis.

In summary, in our series the high percentage of advanced histological lesion in patients with intermittently and moderate ALT levels elevation have recommendable liver biopsy in these cases, independently of other factors as viral load or serological status HBeAg/antiHbe. Other host or viral factors like age, gender or viral genotype will help to decide such indication in individual cases.

\section{REFERENCES}

1. Lavanchy D. Hepatitis B virus epidemiology, disease burden, treatment, and current and emerging prevention and control measures. J Viral Hepat 2004; 11: 97-107.

2. Fattovich G, Giustina G, Schalm SW, Hadziyannis S, Sanchez-Tapias J, Almasio P, et al. Occurrence of hepatocellular carcinoma and descompensation in western European patients with cirrhosis type B. The EUROHEP Study Group on Hepatitis B Virus and Cirrhosis. Hepatology $1995 ; 21: 77-82$.

3. Fattovich G, Bortolotti F, Donato F. Natural history of chronic hepatitis B: special emphasis on disease progression and prognostic factors. J Hepatol 2008: 335-52.

4. Di Marco V, Lo Iacono O, Camma C, Vaccaro A, Giunta M, Martorana $\mathrm{G}$, et al. The long-term course of chronic hepatitis B. Hepatology 1999; 30: 257-64.

5. European Association for the study of the liver. EASL Clinical Practice Guidelines: management of chronic hepatitis B J Hepatol 2009; 50: 227-42.

6. Lock AS, McMahon BJ; Practice Guidelines Committee, American Association for the Study of Liver Diseases (AASLD). Chronic hepatitis B: update of recommendations. Hepatology 2004; 39: 857-61.

7. Keeffe EB, Dieterich DT, Han SH, Jacobson IM, Martin P, Schiff ER et al. A treatment algorithm for the management of chronic hepatitis B virus infection in the United States: 2008 update. Clin Gastroenterol Hepatol 2008; 6(12): 1315-41.

8. McMahon BJ. The natural history of chronic hepatitis B virus infection. Hepatology 2009; 49: S45-S53.

9. Lai M, Hyatt BJ, Nasser I, Curry M, Afdhal NH. The clinical significance of persistently normal ALT in chronic hepatitis B infection. J Hepatol 2007; 47: 760-7.

10. Kumar M, Sarin SK, Hissar S, Pande C, Sakhuja P, Sharma BC, et al Virologic and histologic features of chronic hepatitis b virus-infected asymptomatic patients with persistently normal ALT. Gastroenterology 2008; 134: 1376-84.

11. Piton A, Poynard T, Imbert-Bismut F, Khalil L, Delattre J, Pelissier E, et al. Factors associated with serum alanine transaminase activity in healthy subjects: consequences for the definition of normal values, for selection of blood donors, and for patients with chronic hepatitis C. MULTIVIRC Group. Hepatology 1998; 27: 1213-9.

12. Prati D, Taioli E, Zanella A, Della Torre E, Butelli S, Del Vecchio E, et al. Updated definitions of healthy ranges for serum alanine aminotransferase levels. Ann Intern Med 2002; 137: 1-9.

13. Iloeje UH, Yang HI, Su J, Jen CL, You SL, Chen CJ. Predicting cirrhosis risk based on the level of circulating hepatitis B viral load. Gastroenterology 2006; 130: 678-86

14. Chen CJ, Yang HL, Su J, You SL, Lu SN, Huang GT, et al. Risk of hepatocellular carcinoma across a biological gradient of serum hepatitis B virus DNA level. JAMA 2006; 295: 65-73.

15. Zoulim F, Perrillo R. Hepatitis B: reflections on the current approach to antiviral therapy. J Hepatol 2008; 48(Supl. 1): S2-19. 
16. Papatheodoridis GV, Manesis EK, Manolakopoulos S, Elefsiniotis IS, Goulis J, Giannousis J, et al. Is there a meaningful serum hepatitis B virus DNA cuttof level for therapeutic decisions in hepatitis B e antigen-negative chronic hepatitis B virus infection? Hepatology 2008; 48: 1451-9.

17. Sánchez-Tapias JM, Costa J, Mas A, Bruguera M, Rodés J. Influence of hepatitis b genotype on the long-term outcome of chronic hepatitis B in western patients. Gastroenterology 2002; 123: 1848-56.

18. Miyakawa Y, Mikozami M. Classifying hepatitis B virus genotypes. Intervirology 2003; 46: 329-38.

19. Knodell RG, Ishak KG, Black WC, Chen TS, Craig R, Kaplowitz N, et al. Formulation and application of a numerical scoring system for assessing histological activity in asymptomatic chronic active hepatitis. Hepatology 1981; 1: 431-5.

20. Scheuer PJ. Classification of chronic viral hepatitis: a need for a reassessment. J Hepatol 1991; 13: 372-3.

21. Taylor BC, Yuan JM, Shamliyan TA, Shaukat A, Kane RL, Wilt TJ. Clinical outcomes in adults with chronic hepatitis $b$ in association with patient and viral characteristics: a systematic review of evidence. Hepatology 2009; 49: S85-S95.
22. Huo TI, Wu ML, Hwang SJ, Lai CR, Lee PC, Tsay SH, et al. Factors predictive of liver cirrhosis in patients with chronic hepatitis B: a multivariate analysis in a longitudinal study. Eur J Gastroenterol Hepatol 2000; 12: 687-93

23. Park BP, Park YN, Ahn SH, Lee KS, Chon CY, Moon YM, et al. Long-term outcome of chronic hepatitis B based on histological grade and stage. J Gastroenterol Hepatol 2007; 22: 383-8.

24. Chen CJ, Yang HI, Iloeje UH; for the REVEAL-HBV Study Group. Hepatitis B virus DNA levels and outcomes in chronic hepatitis B Hepatology 2009; 49: S72-S84.

25. Yang HI, Lu SN, Liaw YF, You SL, Sun CA, Wang LY, et al.; for the Taiwan Community-Based Cancer Screening Project Group. Hepatitis B e antigen and the risk of hepatocellular carcinoma. N Engl J Med 2002; 347: 168-74

26. Kramvis A, Kew MC. Relationship of genotypes of hepatitis B virus to mutations, disease progression and response to antiviral therapy. $\mathrm{J}$ Viral Hepat 2005; 43: 411-7.

27. Kew MC, Kramvis A, Yu MC, Arakawa K, Hodkinson J. Increased hepatocarcinogenic potential of hepatitis B virus genotype A in Bantu-Speaking Sub-Saharan Africans. J Med Virol 2005; 75: 513-21. 